\title{
Follow The Money Approach in The Management of Fishing Criminals by Fisheries PPNS
}

\author{
Rizki Zakariya \\ Faculy of Law, Indonesia Jentara Law School \\ Jl. Kuningan Madya Kav. 5-6, Kel. Guntur, Kec. Setiabudi, Jakarta City, DKI Jakarta 12980
}

\begin{tabular}{ll}
\hline Article Info: & $\begin{array}{l}\text { Submitted April 6, } 2020 \text { Accepted April 26, } 2020 \\
\text { Published May 9, 2020 }\end{array}$
\end{tabular}

\begin{abstract}
s :
The many cases of Illegal Fishing, threaten the wealth of fisheries and sovereignty of Indonesia. This study aims to explain the urgency of the Follow the Money approach in handling fisheries crime cases by PPNS Fisheries. Then provide concrete recommendations for the Follow the Money implementation in handling fisheries crime cases. This paper is a normative juridical study, which is processed qualitatively. The results of this study indicate the urgency of the Follow the Money approach in handling fisheries crime cases by PPNS Fisheries due to Indonesia's large fishery wealth; the magnitude of the threat of illegal fishing in Indonesia; lack of fisheries crime cases handled by PPNS Fisheries; and the development of the modus operandi of fisheries criminals.
\end{abstract}

Keywords: Illegal Fishing, Follow the Money, PPNS Fisheries.
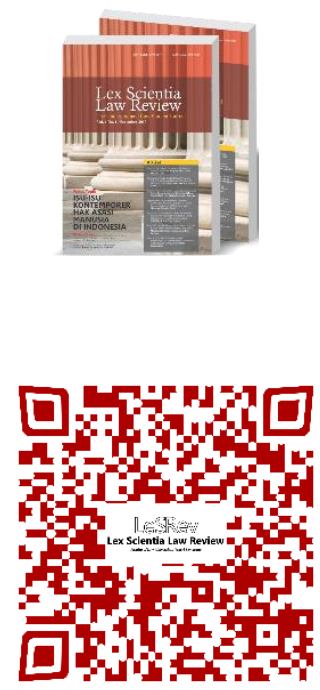

Vol. 4, No. 1

Month May Year

2020

Abstrak:

Banyaknya kasus Illegal Fishing, mengancam kekayaan perikanan dan kedaulatan Indonesia. Penelitian ini bertujuan untuk menjelaskan urgensi pendekatan Follow the Money dalam penanganan perkara kejahatan perikanan oleh PPNS Perikanan. Kemudian memberikan rekomendasi konkret implementasi Follow the Money dalam penanganan perkara kejahatan perikanan. Tulisan ini adalah studi yuridis normatif, yang diolah secara kualitatif. Hasil penelitian ini menunjukkan urgensi pendekatan Follow the Money dalam penanganan perkara kejahatan perikanan oleh PPNS Perikanan karena kekayaan perikanan Indonesia yang besar; besarnya ancaman illegal fishing di Indonesia; minimnya perkara kejahatan perikanan yang ditangani PPNS Perikanan; dan berkembangnya modus operandi pelaku kejahatan perikanan.

Kata Kunci : Illegal Fishing, Follow the Money, PPNS Perikanan.

\section{Citation :}

Rizki Zakariya. (2020). Follow the Money Approach in The Management Of Fishing Criminals By Fisheries PPNS. Lex Scientia Law Review 4(1), 103-118, doi: https://doi.org/10.15294/lesrev.v4i1.38161 


\section{Introduction}

Indonesia is one of the maritime countries in the world. That is because Indonesia has a vast ocean and a large sea wealth in it. Two-thirds of Indonesia's territory is ocean, which reaches 6.4 million $\mathrm{km}$, and the second largest sea length in the world reaches $108,000 \mathrm{~km} \cdot{ }^{1}$ In addition, Indonesia's oceans have great marine wealth and diversity, both recoverable resources (fisheries, mangrove, coral reefs, etc.), as well as non-recoverable resources (oil and gas, and other mining products). ${ }^{2}$ The great wealth and potential of Indonesia's seas are followed by various crimes at sea, especially fisheries. This is done by foreign vessels that catch fish in Indonesia illegally (Illegal Fishing), thus harming the Indonesian economy up to IDR 300 Trillion per year. ${ }^{3}$ This Illegal Fishing also impacts in economic losses, fisheries crimes that reduced fishing yields of Indonesian fishermen, even the stunting condition of Indonesian children. Regarding these problems, the Government made efforts to secure and protect the Indonesian sea. Law enforcement is an effort used by the government to stop the Illegal Fishing. In addition, the Government also convicts, forms a special judicial institution for fisheries criminal offence, and special investigators who handle fisheries criminal acts, one of which is the Fisheries Civil Servants (Penyidik Pegawai Negeri Sipil/PPNS). These efforts are regulated through The Act Number 45 of 2009 concerning Amendments to The Act Number 31 of 2004 concerning Fisheries.

PPNS Fisheries are investigators from the Ministry of Maritime Affairs and Fisheries (KKP) who is authorized to conduct investigations of criminal acts of fisheries. However, despite its authority and responsibility, efforts to investigate fisheries criminal acts by the Fisheries PPNS are classified as minimal each year. Where in 2018 fisheries criminal acts investigated by PPNS Fisheries reached 9 cases, 2017 reached 2 cases, and 2016 reached 4 cases. ${ }^{4}$ At least the matter was dealt with in reverse with the number of fishery cases decided by the Fisheries Court, which in 2018 reached 587 cases, 2017 reached 692 cases, and 2016 reached 454 cases. ${ }^{5}$ The case of fisheries entering the Court of Fisheries in large numbers apart from the fisheries civil servants came from the handling of the case of the RI Police investigator and the Military Police Investigator AL. This indicates less than the maximum role of Fisheries PPNS in conducting investigations of fisheries cases in Indonesia due to limited personnel and other causes. Therefore, government need to made more efforts to improve the quality of case handling conducted by PPNS Fisheries to prevent and crack down on fisheries criminal offenses.

Follow the Money is an approach that can be used by PPNS Fisheries in snaring fisheries offenders. Through this approach a criminal offender (plegen), a crime scene (locus delicti), and time of the crime (tempus delicti) can be tracked. In addition, the Follow the Money approach has the advantage of tracking assets of a crime, so that it

\footnotetext{
${ }^{1}$ Satuan Tugas 115. (2019). Penegakan Hukum Illegal Fishing di Indonesia. Jakarta: Mas Achmad Santosa. Retrived From :https://wriindonesia.org/sites/default/files/Presentasi\%20SATGAS\%20115\%20\%28Kemenkomar\%2C\%20Me i\%20 2019\%29.pdf. Accessed on May 12020

${ }^{2}$ Stanis, S. (2007). Pengelolaan Sumberdaya Pesisir Dan Laut Melalui Pemberdayaan Kearifan Lokal Di Kabupaten Lembata Propinsi Nusa Tenggara Timur. Jurnal Pasir Laut, 2, 67-82. Retrieved from http://eprints.undip.ac.id/4382/1/6-Stefanus-S.pdf. Accessed on May 12020

${ }^{3}$ Potensi Sumber Daya Ikan Semakin Besar, Retrieved from https://indonesia.go.id/narasi/indonesia-dalamangka/sosial/potensi-sumber-daya-ikan-semakin-besar. Accesed On May 12020

${ }^{4}$ Ishartini. (2019). Laporan Tahunan KKP Tahun 2018. Jakarta: Kementerian Kelautan dan Perikanan RI. p. 18.

${ }^{5}$ Elvitrasyah, T., et. al. (2019). Review Pengadilan Perikanan Dan Hakim Ad Hoc Perikanan. Jakarta: Kementerian Kelautan dan Perikanan RI. p. 6.
}

https://journal.unnes.ac.id/sju/index.php/ls/r/ 
can then be confiscated for the state ${ }^{6}$. This approach is not new in handling criminal cases in Indonesia, where PPNS of the Ministry of Environment and Forestry (KLHK) has taken a Follow the Money approach to eradicate cases of forestry or environmental crimes that occur in Indonesia7. With all the potentials, and comparisons made by the Ministry of Forestry PPNS, then it can also be applied by Fisheries PPNS in eradicating fisheries crime. So that this is the background of this writing. Based on this introduction, the formulation of the problems in this study, as follows: What is the urgency of the Follow the Money approach in handling fisheries criminal cases by PPNS Fisheries? And how is the Follow the Money approach in handling fisheries criminal cases handled by PPNS Fisheries conducted?

Then the purpose of this study is to provide an explanation of the urgency of the Follow the Money approach in handling fisheries criminal cases by the Fisheries PPNS. Then provide concrete recommendations that can be done for the implementation of Follow the Money in handling fisheries criminal cases. So that the law enforcement of fisheries in the Indonesian seas by PPNS Fisheries from the Ministry of Maritime Affairs and Fisheries can held optimally to protect the Indonesian seas.

Efforts to increase the capacity of Fisheries PPNS in law enforcement fisheries criminal acts through the Follow the Money approach is a necessary. This was stated by Soerjono Soekanto (2010) that in the area of law enforcement there are factors that influence the effectiveness of the process. These factors include: 8

a. Legal factors are laws and regulations governing technical enforcement.

b. Law enforcement factors are personnel who carry out their duties in the process of law enforcement.

c. Facilities and infrastructure factors are the equipment used in the process of law enforcement.

d. Community factors are the environmental conditions in which the law is applied.

e. Cultural factors are the association of daily human life that produces works, inventions, and tastes.

Follow the Money, according to Yunus Husein, is an approach commonly used in The Act Number 8 of 2010 concerning the Elimination of Money Laundering (TPPU). In the TPPU the approach is carried out because money launderers hide and disguise the assets resulting from their criminal acts, so that they appear to be legitimate assets. In the Follow the Money approach, which is sought from the beginning of the case, it appears that assets or assets are a crime, not the culprit. ${ }^{9}$ Only after the assets or assets are known as well as the flow of funds are identified. The advantages of using the Follow the Money approach are wider reach, compared to conventional methods in handling cases, because they know the flow of crime funds to anyone involved in the crime. Then it can be done secretly without the need for much media attention or the risk of dealing directly with perpetrators of crime who have the potential to take the fight. Furthermore, it can benefit the country's finances, because assets or assets of criminal acts can be used as evidence to be confiscated until later confiscated to enter the state treasury. In addition, the Follow the Money approach also impacts deterrent

\footnotetext{
${ }^{6}$ PPATK. (2019). Modul E-Learning 1 Pengenalan Anti Pencucian Uang Dan Pendanaan Terorisme. Jakarta: Pusat Pelaporan dan Analisis Transaksi Keuangan. p. 4.

7 Hadi, D. W. (2018). Bench Mark Pembangunan KLHK 2018-2019. Retrieved from http://ppid.menlhk.go.id/siaran_pers/browse/1061. Accesed on Mei 2020

${ }^{8}$ Soekanto, S. (2010). Faktor-faktor Yang Mempengaruhi Penegakan Hukum. Jakarta: PT Raja Grafindo Persada. p. 8.

${ }^{9}$ Husein, Y. (2008). Negeri Sang Pencuci Uang. Jakarta: Pustaka Juanda Tiga Lima. p. 15-20.
} 
criminals and loses motivation because their assets or assets are taken by the state. So, with these advantages, the Follow the Money approach must be applied in handling fisheries criminal cases.

Although this approach is commonly used in money laundering, it does not rule out the possibility of being used in handling other criminal acts. It was like a forest crime case handled by PPNS Ministry of Environment and Forestry which handled the case with the Follow the Money approach. This approach is effective in exposing illegal loggers, to financiers of illegal advocates. In addition, assets can be confiscated as a result of crime for the state. ${ }^{10}$ With this comparison, the Follow the Money approach can also be applied in handling fisheries criminal cases which also have complexity and difficulty in disclosing their cases.

\section{Research Methods}

This research is a normative legal research. Where to get accurate data related to this legal research, the author uses several approaches that are commonly used in legal research are the statute approach, case approach, and comparative approach. ${ }^{11}$ This research was conducted by conducting library research, in the form of secondary data, namely books, research results, journals, articles, and legislation relating to research objects. ${ }^{12}$ To process the various data, in this study a qualitative analysis was carried out, namely by analyzing three aspects, there are classifying, comparing and connecting. ${ }^{13}$

\section{Result and Discussion}

\subsection{The Urgency of the Follow the Money Approach in the Handling of Fisheries Criminal Cases by Fisheries PPNS}

\subsubsection{Condition of Indonesian Fisheries}

Indonesia is one of the maritime countries in the world. That is because Indonesia has a vast ocean and a large sea wealth in it. Two-thirds of Indonesia's territory is ocean which reaches 6.4 million $\mathrm{km} 2 .{ }^{14}$ Then the area of inland sea waters and the archipelago waters reachs 3,110,000 km2; Indonesian territorial sea area is 290,000 km2; Indonesian additional zone area is $270,000 \mathrm{~km} 2$; Indonesian exclusive economic zone area is 3,000,000 km2; and Indonesian continental shelf area is $2,800,000 \mathrm{~km} 2$ with the length of the Indonesian coastline $108,000 \mathrm{~km} 2 .{ }^{15}$ The vast area of the ocean has an impact on the richness and diversity of Indonesia's sea, both reclaimable resources (fisheries, mangrove forests, coral reefs, etc.), as well as non-recoverable resources (oil and gas, and yields other mines). ${ }^{16}$ The potential of fish resources from the Indonesian sea reaches 12.54 million tons per year which is spread throughout Indonesian

\footnotetext{
${ }^{10}$ Ibid.

${ }^{11}$ Marzuki, P. M. (2005). Penelitian Hukum. Jakarta: Kencana Prenada Media Group. p. 93.

${ }^{12}$ Soekanto, S., Sri, M. (2007). Penelitian Hukum Normatif Suatu Tinjauan Umum. Jakarta: Raja Grafindo Persada. p. 23.

${ }^{13}$ Suriasumantri, J. S. (1986). Ilmu dalam Perspektif Moral, Sosial, dan Politik: Sebuah Dialog tentang Keilmuan Dewasa Ini. Jakarta: Gramedia. p. 61-62.

${ }^{14}$ Supranote 1.

${ }^{15}$ Biro Komunikasi. (2018). Menko Maritim Luncurkan Data Rujukan Wilayah Kelautan Indonesia., Retrieved from https://maritim.go.id/menko-maritim-luncurkan-data-rujukan-wilayah- kelautan-indonesia/. Accessed on May 1 on 2020

${ }^{16}$ Supranote 2
} 
waters and the waters of the Exclusive Economic Zone. ${ }^{17}$ From the large potential of Indonesian marine fish, the number of catches allowed is 10.03 million tons per year or $80 \%$ from the total marine potential. 18

The boundaries of the Indonesian Ocean

Territory are based on 1982 LOSC Provisions

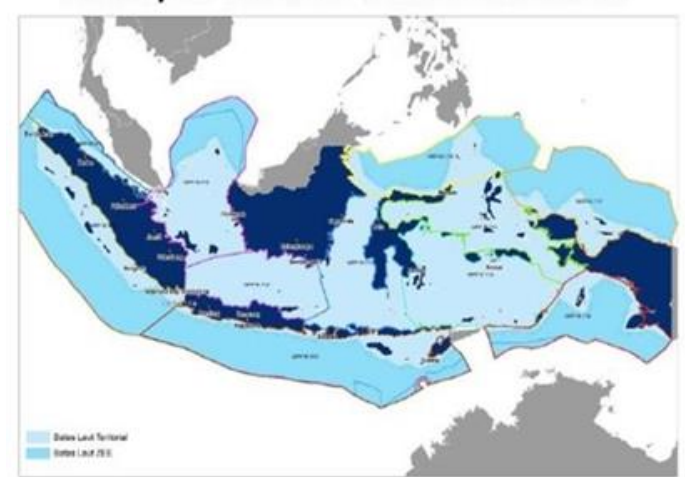

Based on this picture, it is known that the vast Indonesian sea area, which is a place for $37 \%$ of fish species in the world that has a high economic value. ${ }^{19}$ Indonesia has the right to utilize and manage fisheries resources at sea in Indonesia based on the United Nations Convention on the Law of the Sea (UNCLOS) in 1982. This utilization is proven by continuing to increase the production of captured fish from Indonesian seas by Indonesian fishermen, which is seen in the following graph:20

\section{Per capita fish consumption rates}


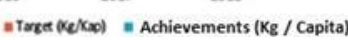

Based on the graph, it is known that Indonesian catch fisheries production from the sea during 2014-2018 increased by an average of $2.82 \%$ per year. Where the total catch fisheries production in 2014 reached 6.5 million tons worth IDR 108 trillion, up to 7.2 tons valued at IDR 140 trillion in 2018. The increase in the amount of fishery catches results in an increase in state tax revenue from the fisheries sector. In addition, increasing the availability of national fish, which also has an impact on increasing consumption of fish per capitas Indonesian people. Following is an increase in taxes from the fisheries sector and national fish consumption in 2014-2018..$^{21}$

Based on the graph, it is known that there is an increase in state tax revenue from the fisheries sector and national fish consumption. On fisheries tax receipts

17 BKIPM. Peringati Hari Guru, Menteri Edhy Kampanyekan Gemarikan., Retrieved from https://kkp.go.id/bkipm/artikel/15486-peringati-hari-guru-menteri-edhy-kampanyekan-gemarikan. Accessed on May 12020

18 Supranote 4

${ }^{19}$ Ibid

${ }^{20}$ Ibid

${ }^{21}$ Ibid

https://journal.unnes.ac.id/sju/index.php/lslr/

Copyright $(2020$ By Authors 
in 2014 reached IDR 851 billion, increased to IDR 1,554 billion in 2018.22 Then the consumption of fish, which was originally only $41.11 \mathrm{~kg} /$ capita / year in 2015, increased to $50.69 \mathrm{~kg} /$ capita / year in $2018^{23}$ So based on this, the increase in fisheries production has a positive impact on the country, society, and fisheries entrepreneurs.

One of the causes of the increase in Indonesian marine fisheries is due to effective law enforcement efforts by the Illegal Task Force on Combating Illegal Fishing (known as Task Force 115). ${ }^{24}$ The task force (Satuan Tugas/Satgas) 115 was formed based on Presidential Regulation Number 115 of 2015 Concerning Illegal Fishing Task Force. Until 2019, it was recorded that 488 ships were destroyed and sunk including 26 Indonesian-flagged vessels that were fishing illegally in Indonesian territory by Satgas 115.25 This gives fear to other criminals who will do it, as well as providing a deterrent effect for the perpetrators who have committed it. This shows that taking assets of fisheries criminals has a significant impact in combating fisheries crimes.

Despite having a good record in efforts to enforce fisheries law, Task Force 115 was finally disbanded on December 31, 2019 because its term of service had ended based on The Government Regulation Number 115 of 2015. The authority for law enforcement on fisheries cases, especially investigations, was carried out by various related agencies as regulated in Article 73 paragraph (1) The Act Number 45 of 2009 concerning Amendments to The Act Number 31 of 2004 concerning Fisheries which reads:

"Investigation of criminal offenses in the field of fisheries in the territory of the Republic of Indonesia fisheries management is carried out by Fisheries Civil Servant Investigators, Navy Officers Investigators, and / or State Police Investigators of the Republic of Indonesia."

The authority to handle fisheries investigation cases in the 3 (three) institutions, so that the eradication of fisheries crime can held optimally. However, the negative impact is overlapping case handling, so cases are difficult to move up to the next stage of the case, because each agency has similar authority. Whereas the crime of fisheries, especially Illegal Fishing will always threaten the Indonesian sea areas. This was based on the findings of the Directorate General of Maritime and Fisheries Resources Supervision (DG PSDKP) on March 10, 2020, which stated that from the beginning of 2020 to March 10, 2020, 10 foreign fishing vessels that had been carrying out Illegal Fishing in the Indonesian sea had been caught. ${ }^{26}$ These vessels are fishermen or foreign fishing companies that do fishing in Indonesia without permission (Illegal Fishing), which includes 8 Vietnamese-flagged vessels, 4 Philippineflagged vessels and 3 Malaysian- flagged vessels. ${ }^{27}$ The locations that often

\footnotetext{
${ }^{22}$ Ibid

${ }^{23}$ Ibid

${ }^{24}$ Kusumawardhani, F. (2019). Susi Ingin Satgas 115 Tetap Basmi Illegal Fishing di Pemerintah Baru., Retrieved from https://kumparan.com/kumparanbisnis/susi-ingin-satgas-115-tetap-basmi- illegal-fishing-di-pemerintah-baru1rsd12r54DE. Accessed on May 12020

${ }^{25}$ Pramugar, R. N. (2019). Antara Bakamla Dan Satgas 115. Jakarta: Pusat Transformasi Kebijakan Publik. h. 2.

${ }^{26}$ Mediaindonesia.com. (2020). Sejak Awal 2020, 10 Kapal Ikan Asing Illegal Ditangkap KKP., Retrieved from https://mediaindonesia.com/read/detail/295722-sejak-awal-2020-10-kapal-ikan-asing- illegal-ditangkap-kkp. Accessed on May 12020

${ }^{27}$ Ibid.
}

https://journal.unnes.ac.id/sju/index.php/Islr/ 
occured Illegal Fishing in the Indonesian sea are in the North Natuna Sea, Malacca Strait and Sulawesi Sea. ${ }^{28}$ Therefore, it is necessary to continue to optimize supervision and enforcement of illegal fishing (Illegal Fishing) in the territory of Indonesia by law enforcement authorities. The efforts to eradicate Illegal Fishing were carried out because the act was detrimental to the state and the people of Indonesia. Based on data from the Ministry of Maritime Affairs and Fisheries, due to the lack of supervision and enforcement of illegal fishing in Indonesian waters, the catching of Indonesian fishermen in 2013 continued to decrease, which only reached 868,414 tons. Whereas in 2003 the catching of Indonesian fishermen reached 1.6 million tons. ${ }^{29}$

Fisherman Households Decreased

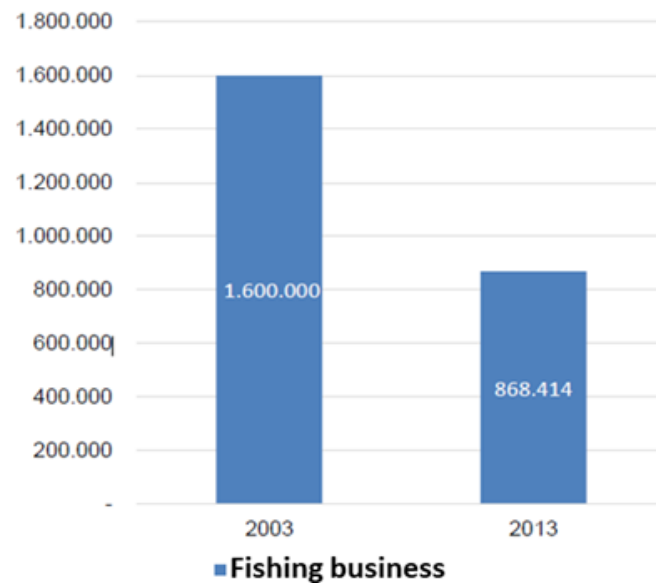

Besides having impact on decreasing fishery yield, Illegal Fishing practices also have an effect on the decline in Indonesian fishery imports-exports abroad. That is can be seen in the comparison of Indonesia's export-import with Thailand in 2000 and 2010.30
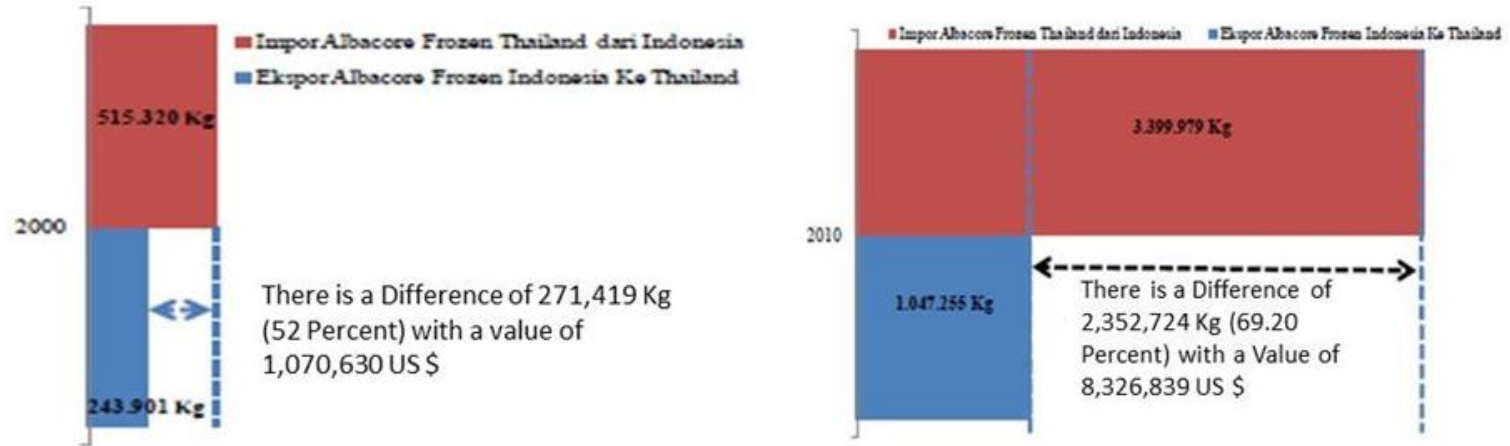

Based on the picture, it is known that there is an imbalance in the number of fishery products coming out of Indonesia to Thailand with data on fishery products entering Thailand from Indonesia. This indicates that Indonesian fish have been stolen, taken and sold abroad by Illegal Fishing. ${ }^{31}$ This is detrimental to the Indonesian economy, both for fishermen, state tax revenues, and the nutritional level of the Indonesian people from fish consumption. Please note,

\footnotetext{
${ }^{28}$ Ibid.

${ }^{29}$ Supranote 1

${ }^{30}$ Ibid

${ }^{31}$ Sufiyanto, T. (2015). Ikan Indonesia Hasil "Illegal Fishing" Dijual di Pasar Dunia., Retrieved from https://www.suara.com/bisnis/2015/01/29/155704/ikan-indonesia-hasil-illegal-fishing-dijual-di- pasar-dunia\#!. Accessed on May 12020
}

https://journal.unnes.ac.id/sju/index.php/IsIr/ 
based on data from the Ministry of Health in 2018 one in three children or 30.8\% of five-year-old babies (Toddlers) in Indonesia experience Stunting. ${ }^{32}$ Stunting is a term for children who are lacking in protein or nutrition, so that they experience stunting or lower height than children their age. ${ }^{33}$

Conditions of Malnutrition in Indonesia

\begin{tabular}{l|l|l|l}
\hline \multicolumn{1}{|c}{ Indikator } & 2007 & $\mathbf{2 0 1 0}$ & $\mathbf{2 0 1 3}$ \\
\hline $\begin{array}{l}\text { The prevalence of short five- } \\
\text { year-old infants }\end{array}$ & 36,8 & 35,6 & 37.2 \\
\hline $\begin{array}{l}\text { Prevalence of children under } \\
\text { five who are thin and very thin }\end{array}$ & 13,6 & 13,3 & 12,1 \\
\hline $\begin{array}{l}\text { The prevalence of babies born } \\
\text { with low body weight <2500 gr }\end{array}$ & 11,5 & 11,1 & 10,2 \\
\hline
\end{tabular}

Source: Riskesdas, 2013

The large number of nutritional deficiencies can be overcome if many people consume fish in meeting their needs. However, the large number of Illegal Fishing activities in Indonesian waters has led to a reduction in the catches of Indonesian fishermen. It further impacts on the availability of national fish. Therefore, it is important to eradicate the perpetrators of Illegal Fishing in Indonesian waters.

\subsubsection{Non-Litigation Pathway}

The effectiveness of law enforcement efforts according to Soerjono Sekanto, one of the factors is the law. These legal factors are laws and regulations governing technical enforcement. In terms of efforts to eradicate Illegal Fishing through the criminal punishment, the culprit has been regulated in The Act Number 45 of 2009 concerning Amendments to The Act Number 31 of 2004 concerning Fisheries (referred to as the Fisheries Act). In the Act, the forms of punishment for the perpetrators of Illegal Fishing in Indonesian waters are regulated, including Article 93 paragraph (2), Article 94, Article 97 paragraph (1) to paragraph (3), and Article 98. One of the Articles used to ensnare the perpetrators of Illegal Fishing is Article 93 paragraph (2) of the Fisheries Law, which reads:

"Every person who owns and / or operates a foreign-flagged fishing vessel conducts fishing in the territory of the Republic of Indonesia fisheries management, which does not have SIPI as referred to in Article 27 paragraph (2), is sentenced to a maximum imprisonment of 6 (six) years and a maximum fine of Rp20,000,000,000.00 (twenty billion rupiah). "

In addition to regulating the criminal prosecution of Illegal Fishing, the Fisheries Act also specifically regulates law enforcement and justice institutions specifically dealing with fisheries criminal offenses. Regarding the court, it is regulated in Article 71 paragraph (1) of the Fisheries Law which reads:

"With this Law a fisheries court has the authority to examine, hear, and decide on criminal acts in the field of fisheries."

\footnotetext{
${ }^{32}$ Katadata.co.id. (2019). Cek Fakta, 1 dari 3 Balita di Indonesia Mengalami Stunting/Kerdil. Retrieved from https://databoks.katadata.co.id/datapublish/2019/01/16/cek-fakta-1-dari-3-balita-di- indonesia-mengalamistuntingkerdil. Accessed on May 12020 ,

${ }^{33}$ Undip.ac.id. (2018). Satu dari Tiga Balita di Indonesia Alami Stunting., Retrieved from https://www.undip.ac.id/language/id/archives/9040. Accessed on May 12020
} 
The Fisheries Courts are only in North Jakarta, Medan, Pontianak, Bitung, and Tual (Article 71 paragraph (3) of the Fisheries Law). But the jurisdiction throughout Indonesia. Then in the Fisheries Act it also regulates fisheries law enforcement, which conducts investigations and criminal prosecution of fisheries. In the case of investigations, the authorized parties based on Article 73 paragraph (1) of the Fisheries Law are Civil Servant Investigation of Fisheries (Fisheries PPNS), Navy Officers' Investigators, and / or State Police Investigators of the Republic of Indonesia.

Then the authorities in the investigation are regulated in Article 73A of the Fisheries Law, includes:

a. receive a report or complaint from someone about a crime in the field of fisheries;

b. summon and examine suspects and / or witnesses to hear their statements;

c. bring and confront someone as a suspect and / or witness to hear the statement;

d. ransacking fishery facilities and infrastructure suspected of being used in or being a place to commit criminal offenses in the field of fisheries;

e. stop, inspect, capture, carry, and / or arrest ships and / or persons suspected of committing criminal offenses in the field of fisheries;

f. check the completeness and validity of fisheries business documents;

g. photographing suspects and / or evidence of criminal acts in the field of fisheries;

h. bring in the experts required in relation to criminal offenses in the field of fisheries;

i. make and sign the minutes of inspection;

j. confiscate evidence used and / or the results of a criminal offense;

k. stop the investigation; and

1. take other actions which according to law can be accounted for.

In addition, the authority of the investigator besides referring to the Fisheries Act also refers to the regulation of the investigator's authority in The Act Number 8 of 1981 concerning the Criminal Procedure Code (KUHAP), as stated in Paragraph 7 of the General Explanation of the Fisheries Law. So that the Fisheries PPNS is given the authority to force efforts in the context of investigations for the disclosure of cases of fisheries criminal acts.

However, despite being given the authority of forced efforts in the context of investigating fisheries criminal offenses, cases handled by the Fisheries PPNS are classified as minimal each year. This is known from the following annual report of the Ministry of Maritime Affairs and Fisheries in 2018:34

${ }^{34}$ supranote 4 


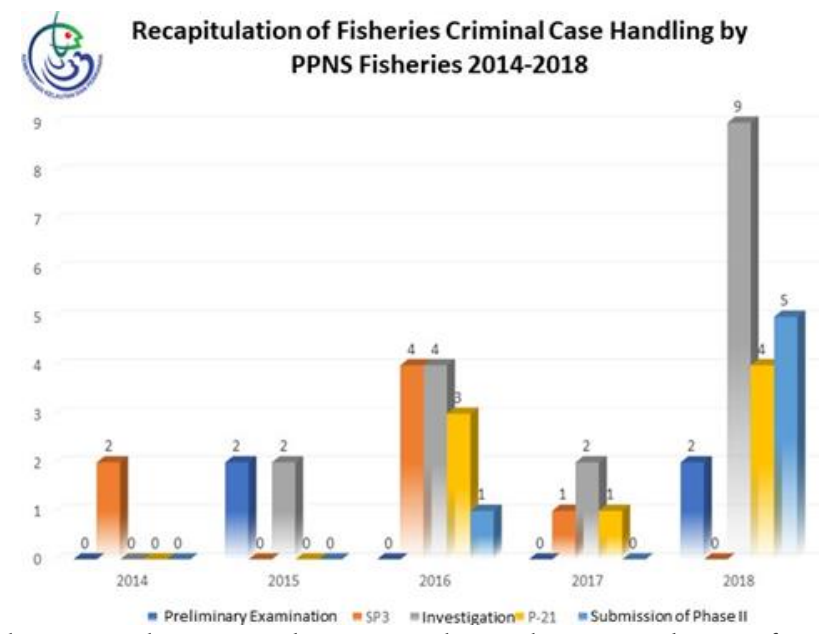

Based on the graph, it is known that the number of cases handled by fisheries criminal investigations by PPNS Fisheries is classified as minimal. That is because in 2014 there were no cases handled, 2015 as many as 2 cases, 2016 as many as 4 cases, 2017 as many as 2 cases, and 2018 as many as 9 cases. One of the factors of the minimum number of investigations handled by the Fisheries PPNS is due to the small number of PPNS personnel, namely only 30 people in $2018 .{ }^{35}$ Even though the workload of fisheries criminal action is almost in all territorial waters of Indonesia.

The number of fisheries criminal investigations handled by the Fisheries PPNS which is classified as minimal is inversely proportional to the number of fisheries crimes that enter the Fisheries Court, which tends to increase every year. Fisheries criminal cases that enter the Fisheries Court can be seen in the following graph: ${ }^{36}$

Statistics of Fisheries Criminal Cases in the Fisheries Court During 2014-2018

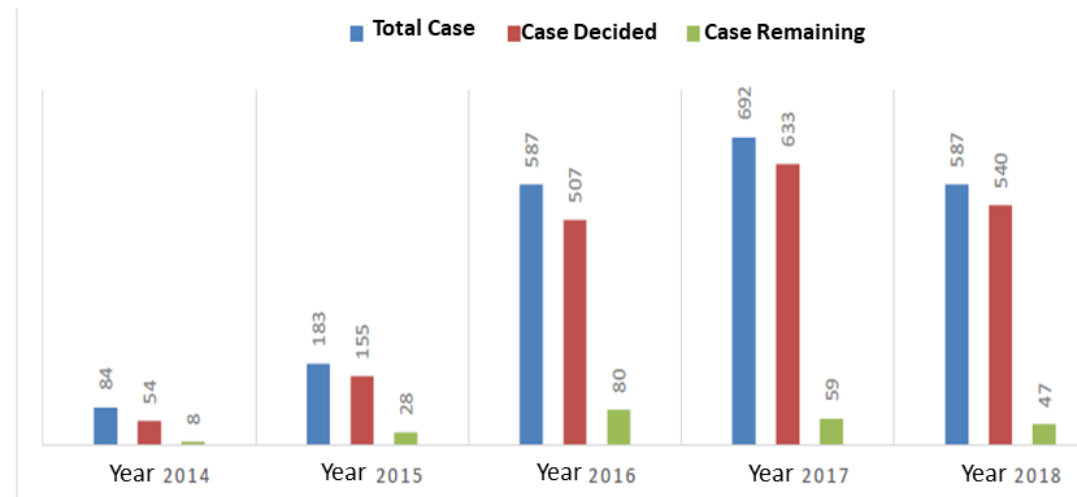

Source: Republic of Indonesia Supreme Court Annual Report 2019

Based on the graph, it is known that the total fisheries criminal cases entered in 2018 reached 587 cases, of which a total of 540 cases were decided, while the remaining 47 have not been decided. The imbalance in the number of cases investigated by the PPNS of Fisheries and those handled by the Fisheries Court shows that the PPNS Fisheries criminal action is not optimal in eradicating fisheries crime, especially Illegal Fishing. Therefore, it is necessary to optimize

\footnotetext{
${ }^{35}$ Ibid

${ }^{36}$ Supranote 5
} 
the handling of cases carried out by Fisheries PPNS in handling fisheries criminal offenses in Indonesian waters. So that it can protect the sovereignty of Indonesian waters from theft of foreign fish that harms the country and the people of Indonesia.

\subsection{Attempts to Follow the Money Approach in Handling Fisheries Criminal Cases by Fisheries PPNS}

The capacity and quality of law enforcement is one of the effective factors in law enforcement, as stated by Soerjono Soekanto (2010). Fisheries PPNS is a law enforcer that handles fisheries criminal offenses in Indonesia. Seeing the lack of fisheries criminal cases investigated, as well as the urgency of the threat of Illegal Fishing that lurks Indonesian waters. Then the optimization efforts must be made to increase the capacity of handling cases of fisheries crime, especially Illegal Fishing. One of the efforts to increase the capacity is the Follow the Money approach in handling fisheries criminal cases by Fisheries PPNS.

Follow the Money, according to Yunus Husein, is an approach commonly used in The Act Number 8 of 2010 concerning the Elimination of Money Laundering. However, although it is common in handling money laundering, the Follow the Money approach does not close for use in handling other criminal cases. ${ }^{37}$ The handling of illegal logging is one of the crimes other than money laundering that has used the Follow the Money approach by PPNS Ministry of Environment and Forestry. This approach has proven to be effective because it can effectively expose the perpetrators of illegal logging, to financiers who fund illegal advocacy. In addition, assets of crime can be found to be confiscated so that they can become state income. ${ }^{38}$ So with the advantages in these cases and other institutions, the Follow the Money approach can also be used in handling fisheries crime, especially Illegal Fishing by PPNS Fisheries. The steps that can be taken to implement the Follow the Money approach include the following ways:

\subsubsection{Increased Collaboration with Financial Transaction Oversight} (Financial Transaction Reports and Analysis Center / PPATK)

The development of Illegal Fishing is not only in the act of stealing fish with a simple mode, but it has evolved into transnational organized crime. This identification is based on the characteristic findings of each illegal fishing case handled. First, the involvement of two or more people involved in the crime. That is because illegal fishing is carried out not by one person, but many person, ranging from fishermen, captains, boat owners, funders, and other parties involved until finally the results are sold. Secondly, the perpetrators of Illegal Fishing operate on an international level. Perpetrators do illegal fishing in other countries that have different jurisdictions, then bring the results to be sold in other countries with different jurisdictions. Third, the perpetrators of money laundering to disguise the results of Illegal Fishing. This was done in order to disguise the detection of law enforcement on his wealth resulting from Illegal Fishing, so that investments were made such as in the infrastructure sector (purchasing new equipment, fish processing, ships and so on), as well as being

\footnotetext{
${ }^{37}$ Supranote 9

${ }^{38}$ Ibid
} 
used for further operational Illegal Fishing purposes. ${ }^{39}$ Therefore, with these offender modes, a Follow the Money approach is needed in handling Illegal Fishing criminal cases whose character is transnational organized crime. Fisheries PPNS play an important role in efforts to realize the approach, which can be done by:

a. Coordination with financial service providers to block assets in the accounts of people suspected or convicted of committing Illegal Fishing;

b. Data requests from financial service providers regarding assets, financial condition, taxation of perpetrators, and other required information in law enforcement;

c. Request assistance from the Financial Transaction Reports and Analysis Center to examine the assets and finances of the perpetrators of Illegal Fishing.

In implementing point a, the Fisheries PPNS must collaborate with Money Laundering investigators to do so. That is because blocking efforts are not regulated in the Criminal Procedure Code or the Fisheries Law. However, it is regulated in Article 71 paragraph (1) of the Money Laundering Law, which is the authority of the money laundering investigator to do so. Whereas point $\mathrm{b}$ and $\mathrm{c}$ can be done by Fisheries PPNS given Article 73A letter 1 of the Fisheries Law which stated:

"Investigators as referred to in Article 73 are authorized: ... l. take other actions which according to law can be accounted for. "

Then affirmed in Article 90 paragraph (1) of Money Laundering Law which reads:

"(1) In carrying out the prevention and eradication of the crime of Money Laundering, the PPATK can cooperate in exchanging information in the form of requests, giving and receiving information with parties, both nationally and internationally, which includes:

\section{... a. law enforcement agencies; "}

The possibility of doing so can facilitate the disclosure of cases, starting from knowing the assets of a fishery crime, the perpetrators, the location of the assets, and the mode of Illegal Fishing conducted, to further arrest the perpetrators, as well as the confiscation of the assets resulting from the crime of fisheries owned.

\subsubsection{Enhancing Collaboration with International Law Enforcement Agencies}

In addition to strengthening cooperation with the national financial supervisory agency, it is also important to further collaborate with international institutions in handling fisheries crime cases, especially Illegal Fishing in Indonesia. This was done because in the Illegal Fishing crime, involving foreign

\footnotetext{
${ }^{39}$ Nadhila, M. S. (2019). Upaya Mengungkap Ruang Gerak Illegal Fishing di Indonesia., Retrieved from http://www.ppatk.go.id/siaran_pers/read/954/upaya-mengungkap-ruang-gerak-illegal-fishing- di-indonesia.html. Accessed on May 12020
} 
actors in the implementation of different legal jurisdictions, making it difficult to disclose cases by law enforcement. ${ }^{40}$

The cooperation of international institutions can be carried out by Fisheries PPNS through bilateral, regional or multilateral agreements based on agreements between countries, as well as between Ministry institutions in other countries. In addition, it can also be through cooperation on good relations with the principle of reciprocity (reciprocity). The forms of cooperation in the implementation are as follows:

a. cooperation with Interpol to conduct searches, arrests, and confiscation of evidence of criminal offenses Illegal Fishing abroad;

b. identification of the person and location of the perpetrators of fisheries crime, and get a statement from a particular person;

c. providing official documents and other legal records related to Illegal Fishing;

d. transferring proceeds of criminal offenses to Indonesian legal jurisdiction to become evidence;

e. tracking, freezing, confiscating and returning assets resulting from criminal acts;

f. deprivation of rights to wealth or clappings that have been obtained or related to an Illegal Fishing fishery crime based on a fisheries court decision in Indonesia or abroad;

g. identification of the identity and activities of the country in which some parts of the series of crimes have taken place;

h. approval of the person who is willing to give testimony or assist in the investigation by the requesting party and if the person is in custody arranges a temporary transfer to the requesting party;

i. expert judgment and notification of results of criminal proceedings.

These efforts are efforts that can be made to Follow the Money approach in handling fisheries crime cases especially Illegal Fishing which is handled by the PPNS of the Ministry of Maritime Affairs and Fisheries.

\subsubsection{Utilization of Electronic Transaction Evidence in Fisheries Criminal Proof}

In addition to collaborating with various national and international institutions, the next Follow the Money implementation effort is the use of electronic transaction evidence in courtroom evidence. This evidence can be obtained from the PPATK report and other institutions that have collaborated with it in the context of disclosure of fisheries criminal cases. So that through the evidence of the transaction can be known the location of assets, relevant actors, and the mode of perpetrators in disguising the results of fisheries criminal acts to be enjoyed.

\footnotetext{
${ }^{40}$ Sofian, A. (2018). Penindakan Dan Penghukuman 'Illegal Fishing', Retrieved from https://businesslaw.binus.ac.id/2018/12/30/penindakan-dan-penghukuman-illegal-fishing/. Accessed on May 12020
} 
Besides as a guide to search for assets, perpetrators, and modes, the use of electronic transaction evidence can also be used to become evidence of criminal acts for confiscation. Article 73A letter $j$ of the Fisheries Law has regulated the authority of Fisheries PPNS to confiscate, which reads:

"Investigators as referred to in Article 73 are authorized: .. j. confiscating evidence used and / or the results of a criminal offense;"

If the evidence of the transaction is in the form of an electronic file, then that can also be evidence at the hearing in the verification and confiscation. Recognition of the existence of electronic evidence in the legal evidence has been regulated in The Act Number 11 of 2008 Regarding Information and Electronic Transactions (called the ITE Law). Where Article 5 paragraph (1) of the ITE Law states that:

"Electronic Information and / or Electronic Documents and / or printouts are legal legal evidence."

Based on the recognition of the existence of electronic evidence, in this case electronic transactions, the Proof of Follow the Money can be carried out. Then it can be revealed and snared by the perpetrators of fisheries crime, even confiscated its assets to then be included in the state revenue cash.

With all the recommendations made above, it is hoped that efforts to handle fisheries criminal cases, especially Illegal Fishing by Fisheries PPNS can held more optimally. So that the Illegal Fishing action in Indonesian waters that harms the country and the people of Indonesia can be prevented and acted on to show the sovereignty of the Indonesian state in Indonesia's own territory.

\section{Conclusion}

Based on the explanation above, the conclusions of this writing are: First, the urgency of the Follow the Money approach in handling fisheries criminal cases by PPNS Fisheries, which is for 4 (four) reasons. First, the large of Indonesia's marine wealth, especially fisheries. Every year the catch of Indonesian fisheries reaches 12.54 million tons, which contributes to meeting the needs of national fish consumption, large state revenues, and sources of income for millions of Indonesian fishermen. Second, the large of the threat of Illegal Fishing in Indonesian waters. The large potential of fisheries in Indonesian waters has caused many fish thieves to catch fish illegally in Indonesian territory. This is detrimental to Indonesia, due to the reduced yield of fishery fisheries, the lack of meeting the nutritional needs of the community from national fish, and the reduced income of the state fisheries sector. Third, the lack of fisheries criminal cases handled by Fisheries PPNS every year. That is inversely proportional to the case that was tried by the Fisheries Court. So that shows less optimal efforts to handle fisheries criminal cases by PPNS Fisheries. Fourth, the mode of transnational organized criminal crimes perpetrators of fisheries crime, especially Illegal Fishing to trick the detection of law enforcement. With these reasons it is important to make efforts to improve methods of handling cases of fisheries criminal acts by Fisheries PPNS. With this, it is expected that efforts to prevent and enforce fisheries criminal acts by PPNS Fisheries can run optimally.

Then second, the Follow the Money approach in handling fisheries criminal cases by PPNS Fisheries can be done in 3 (three) ways. First, increase cooperation with the Financial Transaction Reports and Analysis Center (PPATK). That's because fisheries criminal offenders often use a mode characterized by transnational organized crime to 
disguise the results of their criminal acts through money laundering. So, to uncover the practice, it is necessary to collaborate with PPATK who can track transactions, assets, and fisheries criminal offenders involved. Second, increased cooperation with international law enforcement agencies. That is because the character of the Illegal Fishing crime that crosses the jurisdiction, making it difficult to handle. With the cooperation with law enforcement agencies abroad, the disclosure efforts, tracking assets / actors can run optimally. Third, the use of electronic transaction evidence in proving fishery crime. Utilization was carried out both in tracking assets, perpetrators, and the mode of perpetrators of fisheries criminal acts based on the data found. Then the evidence is used in court, both for confiscation, and confiscation of assets and then returned to state losses.

\section{Recomendation}

Based on this conclusion, the recommendation that the writer wants to convey is that it is necessary to use the Follow the Money approach in handling fisheries criminal cases by the Fisheries PPNS. This can be done by increasing institutional cooperation between PPNS Fisheries through the Ministry of Maritime Affairs and Fisheries with the Financial Transaction Reports and Analysis Center. Then collaborate with international law enforcement agencies. Next is the optimization of the use of electronic transaction evidence in tracking and proving assets resulting from criminal offenses in fisheries and criminal offenders. The recommendations given are expected to improve the optimal handling of fisheries criminal cases carried out by Fisheries PPNS to maintain the sovereignty of Indonesian Sea Territory.

\section{Acknowledgments}

I thank God for help me in my efforts to write this article. Then I also say thank you to all those who were involved in preparing the article that I wrote. I hope that this article will not only end in publication, but will continue to be criticized, used and included in further research. That's because I realize there are still many shortcomings that I did in this research. Thank You

\section{References}

Books:

Elvitrasyah, T., et. al. (2019). Review Pengadilan Perikanan Dan Hakim Ad Hoc Perikanan. Jakarta: Kementerian Kelautan dan Perikanan RI.

Husein, Y. (2008). Negeri Sang Pencuci Uang. Jakarta: Pustaka Juanda Tiga Lima. Ishartini. (2019). Laporan Tahunan KKP Tahun 2018. Jakarta: Kementerian Kelautan dan Perikanan RI.

Marzuki, P. M. (2005). Penelitian Hukum. Jakarta: Kencana Prenada Media Group. PPATK. (2019). Modul E-Learning 1 Pengenalan Anti Pencucian Uang Dan Pendanaan Terorisme. Jakarta: Pusat Pelaporan dan Analisis Transaksi Keuangan.

Pramugar, R. N. (2019). Antara Bakamla Dan Satgas 115. Jakarta: Pusat Transformasi Kebijakan Publik.

Putra, I.B.W.,\& Dharmawan, N.K.S. (2017). Hukum Perdagangan Internasional. Bandung: PT Refika Aditama.

Soekanto, S. (2010). Faktor-faktor Yang Mempengaruhi Penegakan Hukum. Jakarta: PT Raja Grafindo Persada.

Soekanto, S., Sri, M. (2007). Penelitian Hukum Normatif Suatu Tinjauan Umum. Jakarta: Raja Grafindo Persada. 
Suriasumantri, J. S. (1986). Ilmu dalam Perspektif Moral, Sosial, dan Politik: Sebuah Dialog tentang Keilmuan Dewasa Ini. Jakarta: Gramedia.

Journals

Stanis, S. (2007). Pengelolaan Sumberdaya Pesisir Dan Laut Melalui Pemberdayaan Kearifan Lokal Di Kabupaten Lembata Propinsi Nusa Tenggara Timur. Jurnal Pasir Laut, 2, 6782. Accessed from http://eprints.undip.ac.id/4382/1/6- Stefanus-S.pdf.

\section{Online/World Wide Web}

Biro Komunikasi. (2018). Menko Maritim Luncurkan Data Rujukan Wilayah Kelautan Indonesia. Retrieved from https://maritim.go.id/menko-maritim-luncurkan- datarujukan-wilayah-kelautan-indonesia/, Accessed on May 12020.

BKIPM. Peringati Hari Guru, Menteri Edhy Kampanyekan Gemarikan. Retrieved from https://kkp.go.id/bkipm/artikel/15486-peringati-hari-guru-menteri-edhykampanyekan-gemarikan, Accessed on May 12020.

Hadi, D. W. (2018). Bench Mark Pembangunan KLHK 2018-2019. Retrieved from http://ppid.menlhk.go.id/siaran_pers/browse/1061, Accessed on May 12020.

Indonesia. (2019). Potensi Sumber Daya Ikan Semakin Besar. Retrieved from https://indonesia.go.id/narasi/indonesia-dalam-angka/sosial/potensi-sumberdaya-ikan-semakin-besar, Accessed on May 12020.

Katadata.co.id. (2019). Cek Fakta, 1 dari 3 Balita di Indonesia Mengalami Stunting/Kerdil. Retrieved from https://databoks.katadata.co.id/datapublish/2019/01/16/cek-fakta-1-dari-3- balitadi-indonesia-mengalami-stuntingkerdil, Accessed on May 12020

Kusumawardhani, F. (2019). Susi Ingin Satgas 115 Tetap Basmi Illegal Fishing di Pemerintah Baru. Retrieved from https://kumparan.com/kumparanbisnis/susi- ingin-satgas115-tetap-basmi-illegal-fishing-di-pemerintah-baru-1rsd12r54DE, Accessed on May 1 2020.

Mediaindonesia.com. (2020). Sejak Awal 2020, 10 Kapal Ikan Asing Illegal Ditangkap KKP. Retrieved from https://mediaindonesia.com/read/detail/295722-sejak- awal-202010-kapal-ikan-asing-illegal-ditangkap-kkp, Accessed on May 12020

Nadhila, M. S. (2019). Upaya Mengungkap Ruang Gerak Illegal Fishing di Indonesia. Retrieved from http://www.ppatk.go.id/siaran_pers/read/954/upayamengungkap-ruang-gerak-illegal-fishing-di-indonesia.html, Accessed on May 12020

Satuan Tugas 115. (2019). Penegakan Hukum Illegal Fishing di Indonesia. Jakarta: Mas Achmad Santosa. Rterieved from https://wriindonesia.org/sites/default/files/Presentasi\%20SATGAS\%20115\%20\%28Kemen komar\%2C\%20Mei\%202019\%29.pdf, Accessed on May 12020.

Sofian, A. (2018). Penindakan Dan Penghukuman 'Illegal Fishing'. Retrieved from https:// business-law.binus.ac.id/2018/12/30/penindakan-dan-penghukumanillegal-fishing/, Accessed on May 12020.

Sufiyanto, T. (2015). Ikan Indonesia Hasil "Illegal Fishing" Dijual di Pasar Dunia. Retrieved from https://www.suara.com/bisnis/2015/01/29/155704/ikan- indonesia-hasilillegal-fishing-dijual-di-pasar-dunia\#!, Accessed on May 12020.

Undip.ac.id. (2018). Satu dari Tiga Balita di Indonesia Alami Stunting. Retrieved from https://www.undip.ac.id/language/id/archives/9040, Accessed on May 12020

\section{Laws and Regulations}

The Act of the Republic of Indonesia Number 8 of 1981 concerning the Criminal Procedure Code. December 31, 1981. State Gazette of the Republic of Indonesia Year 1981 Number 76.

The Act of the Republic of Indonesia Number 31 of 2004 concerning Fisheries. October 6, 2004. State Gazette of the Republic of Indonesia of 2004 Number 118.

The Act of the Republic of Indonesia Number 45 of 2009 concerning Amendments to Law Number 31 of 2004 concerning Fisheries. October 29, 2009. State Gazette of the 
Republic of Indonesia Year 2009 Number 154.

The Act of the Republic of Indonesia Number 8 of 2010 concerning Prevention and Eradication of Money Laundering Crimes. October 22, 2010. State Gazette of the Republic of Indonesia Year 2010 Number 122.

The Act of the Republic of Indonesia Number 11 Year 2008 Regarding Information and Electronic Transactions. April 21, 2008. State Gazette of the Republic of Indonesia Year 2008 Number 58. 